\title{
Effects of International and Internal Remittanaces on Financial Inclusion in Ghana
}

\author{
http://doi.org/ 10.21272/fmir.4(3).109-123.2020
}

\section{John Gartchie Gatsi}

Associate Professor of Finance, the Department of Finance, School of Business, University of Cape Coast, Ghana

\begin{abstract}
This article examines the relationship between remittances and financial inclusion in Ghana. The data for the study was extracted from the results of an analytical review of the living standards survey indicators in Ghana. The methodological tools of the study are represented by a regression equation based on the use of the Force Entry Method to test the functioning of variables in the model. The study empirically confirms and theoretically proves that domestic remittances have a positive and significant impact on access to financial services, while international remittances affect the likelihood of opening a bank account, but do not have any significant impact on applying for a loan and lending to remittance households. It is substantiated that domestic and international money transfers have a significant positive impact on the opening of bank accounts, even when forging collateral. Based on the results of calculations, the paper substantiates the conclusion that remittances contribute to increasing the availability of financial services in Ghana. It was noted that domestic remittances have a greater potential to improve financial inclusion in Ghana than international remittances. The paper emphasizes that the provision of collateral is an important lever for lending to households. Remittances will have very little impact on financial inclusion when financial institutions require collateral to facilitate the application and grant. According to the results of the study, the following recommendation were provideds: development of a strategy to improve domestic remittances to increase indicators of financial inclusion and economic development; improving the conditions for remittances, especially domestic remittances, in order to ensure their flexibility and deepen financial integration; use of domestic remittances as collateral for household loans.
\end{abstract}

Keywords: collateral, financial inclusion, financial institutions, Ghana, remittances, loan application, migration.

JEL Classifications: G51, D14, G21.

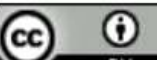

Cite as: Gatsi, J. G. (2020). Effects of International and Internal Remittanaces on Financial Inclusion in Ghana. Financial Markets, Institutions and Risks, 4(3), 109-123. http://doi.org/ 10.21272/fmir.4(3).109-123.2020.

(C) The Author, 2020. This article is published with open access at Sumy State University.

\section{Introduction}

Remittances are related to migration of people historically. In 2014, the World Bank reported that more than 200 million people are living in places other than their places of birth and this number continues to rise yearly. The migrants remit income to their home countries for various reasons including repayment of loans, funeral donations and establishment of small businesses for family members, contribution to family financial needs and personal investment (Aga \&MertinezPeria, 2014). Developing countries in Africa, Asia and Latin America benefit a lot from remittances even though there are also outward remittances outside these countries to relatives in advanced economies mainly for the payment of school fees (Anyanwu \& Erhijakpor,2010). They further explained that there is internal remittances where people remit money to support building projects, family support and investments though the recipients and senders of the remittance moneys live in the same country but in different locations. In most countries in Africa such as Kenya, Uganda, Ghana, Tanzania, Rwanda, mobile money applications have made internal remittances convenient, flexible and efficient. The sending and receipt of remittances has become a global concern over the years and researchers are interested in finding out the contribution of remittances to economic development in both micro and macro levels in host and home countries. 
Demirguc-Kunt, et. al (2011) explain remittances as the cash and goods that are transferred to households by migrant workers who live outside the countries or communities they come from and are currently working in another country or community. They also explained that remittances may contribute to opening of bank accounts with financial institutions by the recipients. In 2010, the flow of remittances to African countries alone was US\$40 billion making up 2.6\% of Africa's GDP (World Bank, 2011). In 2017, remittances contributed more than US\$2.2billion to the gross domestic product (GDP) of Ghana (World Bank, 2018). Though remittances contributed immensely to the economic growth and development of both home and host countries, (Aga \&Mertinez Peria 2014) argued that the cost of remittance transfer and payment of commission to intermediaries may reduce the inherent benefits.

Financial inclusion has become an important area of studies when discussing migration and remittances. Studies have established that financial inclusion beneficial from remittances especially when various transfer applications are used including mobile money applications. It encourages effective distribution of funds (Ajefu \& Ogebe, 2019) better access to finance, thus leading to faster correction of income disparity (Beck \& Demirguc-Kunt, 2008; Honohan 2004), poverty reduction (Chibba, 2009). While these scholars believe that remittances positively influence financial inclusion, others believe remittances have no influence on financial inclusion. Anzoategui, Demirgüç-Kunt and Pería (2014) found a positive and significant impact of remittances on bank credit and bank deposit, while other empirical studies such as Guliano and Ruiz-Arranz (2009) found contrary evidence that remittances relax the financial constraint of the receiving household. This reduces the demand for loans from financial institutions with negative impact on financial inclusion. The two different schools of thought have raised the concern to examine whether or not remittances have any impact on financial inclusion in Ghana considering the migration rate of $48.6 \%$ and annual remittance of GHC2.2billion contribution to GDP in 2017 (World bank ,2018). With the level of remittances flow in Ghana, there is the need to gain a proper understanding and clarity on the effect of remittances on financial inclusion. This study deviates from other existing studies on Ghana that examined only the impact of external remittances on economic growth.

The justification for Ghana as a study area is emphasized because there is limited and mostly inaccurate data on internal and external remittances, (Anzoategui et al., 2014). Githaiga and Kabiru (2014) advocated for more study on remittances and financial inclusion especially in developing countries where data is limited. This paper examines the extent to which internal and international remittances influence financial inclusion in Ghana.

\section{Literature Review}

Monahov, A. (2020) remittances have been reliable source of income and capital for households in small and emerging economies over many decades. The emergence of Covid-19 has therefore impaired liquidity stability for households in countries with underdeveloped financial markets. Financial inclusion is about using various tools such as technology and policies to integrate people into the formal financial services space irrespective of whether or not the recipients engage in economic activities. According to Mbutor and Uba (2013) financial inclusion is a strategy aimed at increasing the number of people in an economy who are banked and hence holding a formal bank account with banks and other formal financial institutions. Beck et al. (2006) also defined financial inclusion is a banking sector outreach that allows access to formal financial services and their use by households and organizations. In recent times financial inclusion encourages people to engage in formal financial system using mobile phones and the internet without necessarily holding a formal bank account. Thus financial inclusion aims at advancing the use of formal mode of payments, including cheques, ATM cards, internet payments, mobile payments and others by the populace. Financial inclusion is achieved by ensuring the ease of accessibility of financial services, its availability, and making use of formal financial system for all members of an economy (Shankar, 2013). Financial inclusion also serves as financial deepening due to its role in increasing the size of financial system, growing diversification of firms' and households' portfolios and developing the financial markets (Ajefu \& Ogebe, 2019).

Mbutor and Uba (2013) explained that financial inclusion is the process that guarantees easy access, availability, and use of financial services for all participants in an economy. Embedded in this definition are the three main dimensions of financial inclusion- banking penetration (Bank accessibility), availability of banking services and the usage dimension. 
Banking penetration is described by (Mbutor and Uba 2013) as the "the size of 'banked' population, that is, the proportion of people having a bank account. Alternatively, bank accessibility can be accomplished by counting the number of accounts that are opened through financial institutions and approximating the percentage of the citizenry with an account. Availability of banking services dimension measures the extent to which banking service is readily obtainable to people as and when it is needed. Gautam (2019). measured availability of banking service by "the number of bank outlets (per 1000 population) and/or by the number of ATM per 1000 people".

The dimension of usage represents the degree to which a person who holds an account with financial institution utilizes the banking services. Kempson et al. (2004) found that many people merely have accounts with financial institutions but barely utilize the service the financial institutions provide. Sarma (2008) measured the usage dimension as a proportion of the volume of credit and deposit to GDP.

Githaiga (2014) and Nyamongo et al. (2009) concluded that remittances are a cross-border earnings that migrants send to their countries of origin. Remittances maybe cross regional or districts receipts within the same country when it is described as internal remittance.

\section{Empirical review}

\section{Remittances and financial development}

Naceur, Chami \& Trabelsi, (2020) remittances play crucial roles in financial inclusion in least developed and failed States to support household incomes and national economic development (Tweneboah, Gatsi \& Asamoah,2019). Financial market development plays a key role in cost effective remittances. Gatsi, Idun \& Mensah(2020) remittances are important because the can influence depreciation and financial development. In an efficient financial market with innovative fund transfer institutions, migrants are able to scale up the amount of money they send to their home countries. Many studies show that remittances correlate with indicators of financial development. For instance, (Gautam, (2019), Giuliano \& Ruiz-Arranz 2005) found a robust positive impact of remittance on financial development. Moreover, threshold analyses revealed that remittances appear to substitute a well-developed financial system by promoting growth more robustly in those countries with weak financial systems. Aga and Martinez Peria (2014) employed data from about 10,000 households in some selected Sub-Sahara Africa countries and postulated that international remittances from migrants to the countries with high tendency to use formal bank accounts. This affirmed the study by Ambrosius (2012) that established a correlation between remittances and financial development. In both developed and developing countries, there is positive relationship between remittance and financial development (see Aggarwal et al., 2010; Ojapinwa \& Bashorun, 2014). Remittances also play a significant role in solving the liquidity constraint and provide alternative way of financing investment (Giuliano \& RuizArranz, 2009).

Woodruff and Zenteno (2004) argued that remittances do not only enhance financial development, but also promote entrepreneurial activities as well. Extent literature further reports that remittances influence investment (Adams \& Cuecuecha , 2013), economic growth (see Abida \& Sghaier 2014; Busch et al., 2002; Barajas et al., 2009; Imai et al., 2014), development( Sulemana, Bugri Anarfo \& Quartey, 2019). , health (De Haas, 2010), reduces poverty (Adams 2004; Adams 2008; Adams \& Page, 2005; Gupta, Pattillo \& Wagh, 2009; Imai et al., 2014; Kapur, 2003) which are all indicators of economic growth and wellbeing . Coulibaly (2015) argued that though remittances may positively impact financial development in some countries, but not in other countries. Anzoategui et al. (2014), did not find any relationship between remittances and the loan outcome of households, though there is a positive correlation with deposit account of households. Quartey, Ackah and Lambon-Quayefio (2019) found inter-linkages between remittances and savings in Ghana. They explained that during times of crisis remittances flow may slow and when economic activities in the host country are robust migrant remittances may surge. Eftimoski \& Josheski, (2020) in developing economies, household consumptions maybe volatile but remittances can reduce the level of disruptions over time. In developing economies (Cuadros-Meñaca,2020) remittances may serve as entrepreneurial capital, support for education, health insurance and for burial of family members.

\section{Theoretical review}

Taylor (1999) distinguished between pessimistic and optimistic views underpinning remittances. Optimistic Views are rooted in Neo-Classical and Developmentalist theories. The Neo-Classical theory considers remittances flow as a means of optimizing resource distribution to benefit both the sending and the receiving 
countries. Inclusive redistribution of resources enhances the chance of economic growth (Todaro, 1969). "The theory, however states that an unconstrained movement of labor in a free market will lead to an increment in the marginal cost of production of labour that arises from the scarcity of labor in the migrant's sending country". The flow of remittance capital, is expected to move in an exactly opposite direction as migration of labour and hence leading to a factor price equalisation (the Heckscher-Ohlin model). The recipients of remittance money and how much to receive maybe defined by financial market tools that enhance participation hence financial inclusion.

Pessimistic views is rooted in the cumulative causation and the "Migrant Syndrome". Thus, the pessimists see migration as the major cause of disparity between the developed and the under-developed countries. Migrants are usually educated young men and women who easily get jobs. Remittances are sent to migrants' households, who are often better-off, tend to further deepen the income inequality in the migrants' country of origin (Lipton, 1980). The exposure of wealth of remittances receiving households has the propensity of changing the local taste of these households and leads to an increase in foreign demand (Lipton, 1980). This opposes the neoclassical view that remittances reduce poverty and inequality. Remittances maybe a continuous process that demands the use of financial services products and tools to effectively send or receive funds.

\section{Model Specification and Data}

This paper investigates whether international and internal remittances have impact on financial inclusion in Ghana. Financial inclusion includes bank accounts opening, loan request and loan grant. The dependent variables used in the model are dummy (Yes/No) in nature which include whether or not a household member has requested for a loan in the six months prior to the survey, whether or not the loan was granted and finally, whether a member of the household has a formal bank account with registered financial institution. The paper used binary logistic regression which models how binary response variables depend on a set of explanatory variables, which can be categorical, continuous or a mix of both of them in a model. The study used an annual cross-sectional data and the data was derived from Ghana Living Standard Survey round (GLSS6) which summarizes information on the living conditions and well-being of households in Ghana from the period 18th October 2012 to 17 th October 2013 and has been in use until a new survey report was published. Out of 18,000 households, 16,772 households were successfully enumerated. The study does not change to GLSS7 because the paper has been produced and under review before the GLSS7 was released in October 2018. Remittances, as used in the study, comprise goods, cash and non-cash items received and issued by households

The paper examines the impact of remittances on financial inclusion by considering:

1. Remittances influence loan acquisition

2. Remittances influence loan grant

3. Remittances influence opening of bank account

Empirical Models

Using Binary logistic method, the paper employed Forced Entry Method, which by default allows all the predictor variables to be tested in one block to determine their predictive ability while controlling for the effects of other predictors in the model. The models adopt and modify certain household characteristics and human capital variables as used by Adams et al. (2008).

\section{Financial Inclusion Model}

The research seeks to empirically find whether remittances impact financial inclusion in Ghana. The paper adopted the modified model as used by Anzoategui, Demirgüç-Kunt, and Martínez Pería (2011). In their study, which is slightly close to this study, the choice of independent variables was based on education, gender and certain human characteristics. The dependent variable is represented by $\mathrm{Y}$ and $\mathrm{x}$ denotes the explanatory variable(s). In the linear regression it is assumed that the mean may be stated as an equation linear in $\mathrm{x}$, such as:

$Y_{i}=\left\{\begin{array}{c}1 \text { if the household is financial inclusive } \\ 0 \text { otherwis }\end{array}\right.$

The probability of a household being financially inclusive can therefore be written as $\pi_{i}=P\left(Y_{i}=1\right)=$ $P\left(Y_{i}^{*}>\theta\right)$ with $Y_{i}^{*}$ the latent response. 
The model can therefore be generally written as $\log \left(\frac{\mathrm{Y}}{1-\mathrm{Y}}\right)=x \beta+\varepsilon$

\section{Model Specification}

Financial Inclusion $_{i}=\beta_{0}+\beta_{1}$ ExtRemitRec $_{i}+\beta_{2}$ interRemitRec $_{i}+\beta_{3}$ ExtRemitGiv $_{i}+$

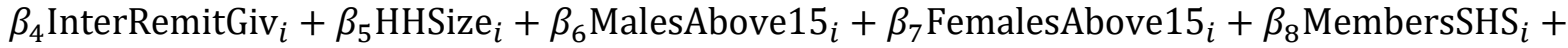
$\beta_{9}$ MembersTer $_{i}+\beta_{10}$ AgeHead $_{i}+u_{i}$

$\underline{\text { Model } 1}$

Loan Application $_{i}=\log \left(\frac{\mathrm{Y}}{1-\mathrm{Y}}\right)=\beta_{0}+\beta_{1}$ ExtRemitRec $_{i}+\beta_{2}$ interRemitRec $_{i}+\beta_{3}$ ExtRemitGiv $_{i}+$

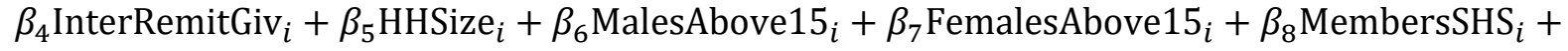
$\beta_{9}$ MembersTer $_{i}+\beta_{10}$ AgeHead $_{i}+u_{i}$

$\underline{\text { Model } 2}$

Loan Grant $_{i}=\log \left(\frac{\mathrm{Y}}{1-\mathrm{Y}}\right)=\beta_{0}+\beta_{1}$ ExtRemitRec $_{i}+\beta_{2}$ interRemitRec $_{i}+\beta_{3}$ ExtRemitGiv $_{i}+$

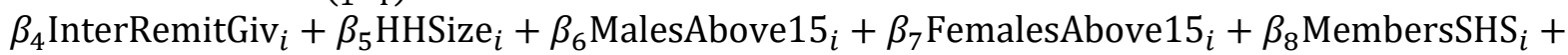
$\beta_{9}$ MembersTer $_{i}+\beta_{10}$ AgeHead $_{i}+u_{i}$

Model 3

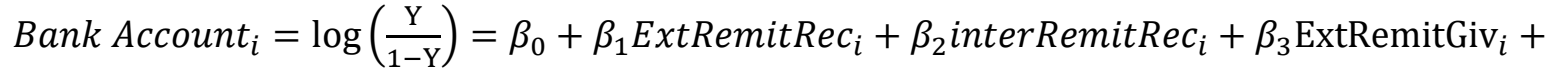

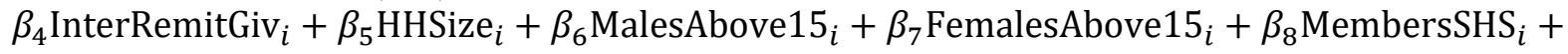
$\beta_{9}$ MembersTer $_{i}+\beta_{10}$ AgeHead $_{i}+u_{i}$

Where;

ExRemitRec is whether or not a member of each of the households receive remittances from abroad, InterRemitRec represents whether or not a member of each of the households receive remittances from other members within Ghana (internal or domestic remittances), ExterRemitGiv represents whether or not households members paid out remittances to others living outside Ghana, and finally, InterRemitRec represents whether or not households' members, from the survey results, paid out remittances to others living within Ghana.

HHSize represents the size of the households under consideration. That is the number of people living in each of the 16772 households. Males above18 represents the number of households that have male members who are 18years and above 18years, whereas Females above18 is the number households with female members who are 18 years and above, Salaries is a dummy variable that denotes whether or not households receive monthly salaries.

On the part of the human capital variables in the model, MembersSHS is the number of households with members who have attained SHS education, and MembersTer is the number of households that have members who have attained tertiary education.

\section{Data}

This section presents an initial summary of the variables being studied. Summary statistics comprising frequencies, means and standard deviations of the variables used in the model are discussed.

Table 1. Descriptive Statistics of the Dependent variables and some independent variables

\begin{tabular}{|c|c|c|c|c|c|c|}
\hline \multirow[b]{2}{*}{ Variables } & \multicolumn{2}{|c|}{ Yes } & \multicolumn{2}{|c|}{ No } & \multicolumn{2}{|c|}{ Total } \\
\hline & Freq. & Per. & Freq. & Per. & Freq. & Per. \\
\hline Loan Application & 1954 & 11.7 & 14806 & 88.3 & 16760 & 100 \\
\hline Loan Granted & 1778 & 10.6 & 14994 & 89.4 & 16772 & 100 \\
\hline Hold Bank Account & 8026 & 47.9 & 8732 & 52.1 & 16758 & 100 \\
\hline Received External Remittances & 13 & 0.1 & 16759 & 99.9 & 16772 & 100 \\
\hline Received Internal Remittances & 773 & 4.6 & 15999 & 95.4 & 16772 & 100 \\
\hline Paid External Remittances & 55 & 0.3 & 16717 & 99.7 & 16772 & 100 \\
\hline Paid Internal Remittances & 493 & 2.9 & 16279 & 97.1 & 16772 & 100 \\
\hline
\end{tabular}

Source: Compiled by the author.

Freq. represents frequency and Per. represents percentage. 
Table 1 shows the summary of the frequencies and percentages for each of the variables. In the case of loan application, 1,954 (11.7\%) out of the 16,760 households responded that they have applied for a loan from financial institutions while 14,806 (88.3\%) indicated that they have not applied for loans in the past six months prior to the survey. With regards to loan granted, only

$1,778(10.6 \%)$ out of the 16,772 respondent households on loan grant, had been granted loan by financial institutions. 852(47.9\%) per cent of the households have an official account with financial institutions and 926(52.1\%) per cent have no account with any financial institution.

This shows that majority of the respondents do not either have access to a financial institution or do not see the need to have a bank account. It is also observed that only $13(0.1 \%)$ households have received remittances from outside Ghana while 773(4.6\%) households out of the total 16,772 households received remittances from people within the country six months to the survey. Again, only 50(0.3\%) household paid external remittances while and $486(2.9 \%)$ households paid internal remittances. Lastly, out of the 16,772 households, only $798(4.8 \%)$ households receive monthly salaries. It is seen that about 15,974 (95.2\%) percent of the households do not receive any monthly salaries.

Table 2. Descriptive Statistics of the independent variables

\begin{tabular}{|c|c|c|c|c|c|}
\hline Variables & Description & Obs. & Sum & Mean & Sd. \\
\hline Hhsize & Total number of respondents in each household & 16772 & 37135 & 2.21 & 1.671 \\
\hline MalesAbove15 & $\begin{array}{c}\text { Number of male members who are above } 15 \text { years in each } \\
\text { of the households }\end{array}$ & 15452 & 35055 & 2.09 & 1.643 \\
\hline FemalesAbove15 & $\begin{array}{l}\text { Number of female members in each of the households under } \\
\text { consideration }\end{array}$ & 15452 & 37317 & 2.22 & 1.723 \\
\hline MembersSHS & $\begin{array}{c}\text { Number of respondents who have attained SHS level of } \\
\text { education }\end{array}$ & 15452 & 4226 & 0.27 & 0.583 \\
\hline MembersTer & $\begin{array}{c}\text { Number of respondents who have attained Tertiary level of } \\
\text { education }\end{array}$ & 15452 & 2856 & 0.18 & 0.509 \\
\hline AgeHead & $\begin{array}{l}\text { Age of each of the heads in all the households under } \\
\text { consideration }\end{array}$ & 16772 & 768831 & 45.84 & 15.898 \\
\hline
\end{tabular}

Source: Compiled by the author.

Table 2 of this paper shows the number, sum, mean and standard deviation of human capital pertaining to education and certain household characteristics variables used in the model. The table indicates that, 37,135 people in all are living in 16,772 households and on average, 2 people live in each of the households. The average number of females and males who are 18 years and above living in 15,452 households each with 35,055 and 37,317 respondents that responded to the survey respectively is 2 . Again, less than one person from each of 15,452 households has attained the secondary and tertiary levels of education. This indicates that the human capital component of the model is low. For instance, the number of households with members having SHS and Tertiary level of education is 0.27 and 0.18 respectively.

Table 3. Crosstabulation showing the relationship between Received External Remittance and Received Internal Remittance

\begin{tabular}{|c|c|c|c|c|c|}
\hline & & & \multicolumn{2}{|c|}{ Internal remittance(rec'd) } & \\
\hline & & & Not received & Received & Total \\
\hline \multirow{12}{*}{$\begin{array}{l}\text { External } \\
\text { Remittances } \\
\text { (Received) }\end{array}$} & Not received & Count & 15995 & 764 & 16759 \\
\hline & & $\begin{array}{c}\% \text { within external remittance } \\
(\text { rec'd) }\end{array}$ & $95.40 \%$ & $4.60 \%$ & $100.00 \%$ \\
\hline & & $\begin{array}{l}\% \text { within internal } \\
\text { remittance(rec'd) }\end{array}$ & $100.00 \%$ & $98.80 \%$ & $99.90 \%$ \\
\hline & & $\%$ of Total & $95.40 \%$ & $4.60 \%$ & $99.90 \%$ \\
\hline & Received & Count & 4 & 9 & 13 \\
\hline & & $\begin{array}{c}\% \text { within external remittance } \\
(\text { rec'd })^{\circ}\end{array}$ & $30.80 \%$ & $69.20 \%$ & $100.00 \%$ \\
\hline & & $\begin{array}{l}\% \text { within internal } \\
\text { remittance(rec'd) }\end{array}$ & $0.00 \%$ & $1.20 \%$ & $0.10 \%$ \\
\hline & & $\%$ of Total & $0.00 \%$ & $0.10 \%$ & $0.10 \%$ \\
\hline & Total & Count & 15999 & 773 & 16772 \\
\hline & & $\begin{array}{c}\% \text { within external remittance } \\
\text { (rec'd) }\end{array}$ & $95.40 \%$ & $4.60 \%$ & $100.00 \%$ \\
\hline & & $\begin{array}{l}\% \text { within internal } \\
\text { remittance(rec'd) }\end{array}$ & $100.00 \%$ & $100.00 \%$ & $100.00 \%$ \\
\hline & & $\%$ of Total & $95.40 \%$ & $4.60 \%$ & $100.00 \%$ \\
\hline
\end{tabular}


Source: Compiled by the author.

From Table 3, out of a total of 16,759 respondent households who received no remittances from abroad, 15,995 (95.4\%) have not also received internal remittances. 764 (4.60\%) who have not received external remittances received internal remittances. Out of the total 13 households who claim to have received external remittances, $4(30.80 \%)$ households received no internal remittances and $9(69.20 \%)$ households, received internal remittances. Out of the total number of 16,772 households who responded as to whether they either received external remittances or not, 15,999 (95.40\%), did not receive internal remittances. 773(4.60\%) households of the 16,772 households received internal remittances.

Table 4. Crosstabulation showing the relationship between Paid External Remittance and Paid Internal Remittance

\begin{tabular}{|c|c|c|c|c|c|}
\hline & & & \multicolumn{2}{|c|}{ Internal remittance(Paid) } & \\
\hline & & & Not Paid & Paid & Total \\
\hline \multirow{12}{*}{$\begin{array}{l}\text { External } \\
\text { Remittances } \\
\text { (Paid) }\end{array}$} & Not Paid & Count & 16234 & 483 & 16717 \\
\hline & & $\%$ within external remittance (Paid) & $97.10 \%$ & $2.90 \%$ & $100.00 \%$ \\
\hline & & \% within internal remittance(Paid) & $99.70 \%$ & $98.00 \%$ & $99.70 \%$ \\
\hline & & $\%$ of Total & $96.80 \%$ & $2.90 \%$ & $99.70 \%$ \\
\hline & Paid & Count & 45 & 10 & 55 \\
\hline & & $\%$ within external remittance (Paid) & $81.80 \%$ & $18.20 \%$ & $100.00 \%$ \\
\hline & & $\%$ within internal remittance(Paid) & $0.30 \%$ & $2.00 \%$ & $0.30 \%$ \\
\hline & & $\%$ of Total & $0.30 \%$ & $0.10 \%$ & $0.30 \%$ \\
\hline & Total & Count & 16279 & 493 & 16772 \\
\hline & & $\%$ within external remittance (Paid) & $97.10 \%$ & $2.90 \%$ & $100.00 \%$ \\
\hline & & $\%$ within internal remittance(Paid) & $100.00 \%$ & $100.00 \%$ & $100.00 \%$ \\
\hline & & $\%$ of Total & $97.10 \%$ & $2.90 \%$ & $100.00 \%$ \\
\hline
\end{tabular}

Source: Compiled by the author.

From table 4 it is observed that out of a total of 16717 households who claimed not to have paid any remittances outside Ghana, 16,234 (97.10\%) who did not pay remittances abroad, did not pay remittances to people in Ghana either. 483 of the households paid remittances to people within Ghana though these households did not pay any external remittances. A total of 55 respondent households paid remittances to other people outside Ghana, out of which $45(81.80 \%)$ of the households who paid remittances abroad, do not give remittances to people within Ghana. Only 10 households out of the 55(18.20\%) households paid internal remittances. Out of the total number of 16,772 households who responded as to whether or not they paid external remittances, 16,279 (97.10\%), did not send internal remittances. 493 (2.90\%) paid internal remittances.

\section{Discussion of Findings}

\section{Remittances and Loan Application}

This sub-section provides findings based on the first objective of this paper-impact of remittances on loan application. Results are presented in Table 5. Logistic regression is used to examine the likelihood that a household will apply for a loan. Results presented include the coefficients (B), the p-values (Sig.) and the odds ratio (Exp (B)). Also reported is some goodness of fit indicators (Omnibus test and Hosmer and Lemeshow test) for the model.

Table 5. Logistic Regression results showing how remittances influence Loan Application

\begin{tabular}{|c|c|c|c|c|}
\hline & \multicolumn{3}{|c|}{ Loan Application } \\
\hline & & B & Sig. & $\operatorname{Exp}(B)$ \\
\hline & Received External Remittance & -19.530 & .999 & .000 \\
\hline & Received Internal Remittance & $.233^{*}$ & .038 & 1.262 \\
\hline & Paid External Remittance & .517 & .150 & 1.677 \\
\hline & Paid Internal Remittance & $.586^{* * *}$ & .000 & 1.797 \\
\hline & HHSize & $-.112 * * *$ & .000 & .894 \\
\hline & MalesAbove15 & -.024 & .580 & .976 \\
\hline & FemalesAbove15 & .031 & .134 & 1.031 \\
\hline & MembersSHS & -.014 & .762 & .986 \\
\hline & MembersTer & $.081 *$ & .023 & 1.085 \\
\hline & AgeHead & .001 & .614 & 1.001 \\
\hline & Constant & -2.060 & .000 & .127 \\
\hline Pseudo $\mathrm{R}^{2}$ : & Cox \& Snell R Square & 0.06 & & \\
\hline & Nagelkerke R Square & 0.11 & & \\
\hline Omnibus Test & & $81.298^{* * *}$ & .000 & \\
\hline Hosmer and $\mathrm{L}$ & Test & 13.475 & .097 & \\
\hline
\end{tabular}

Source: Compiled by the author. 
From table 5, the coefficient for received internal remittance is 0.233 with an odds ratio greater than 1 . This indicates that as more households receive internal remittances, the chances that they will apply for loans increases. In relation to the odds ratio of 1.262 , the implication is that households that received internal (domestic remittances) are 1.262 times more likely to apply for loans than households that do not receive remittances within Ghana. Again, households that paid remittances to others living within Ghana have positive impact on the request for loans, with an odds ratio of 1.79 greater than 1 . This implies that as more households paid out remittances to people within Ghana, the higher will be the probability of loan application. Again, it is observed from Table 5 that households that have members who have attained tertiary education are 1.085 times more likely to request for loans from financial institutions than households without members with tertiary education. This is in line with the findings of Todaro (1976) and Shultz (1982) that as people pursue higher education they secure a better job and hence have the requirement for loan application from financial institutions. Again, households that have salaried workers are more likely to request for loans than households without salaried workers as members. This is due to the fact that the loan application process and requirement for salaried workers is less cumbersome

\section{Remittances and Loan Grant}

The second objective of this paper is to examine how remittances influence the acquisition of loans. Results are presented in Table 6. Logistic regression is used to examine the likelihood that a household loan will be granted. Results presented include the coefficients (B), the p-values (Sig.) and the odds ratio (Exp(B).

Table 6. Logistic Regression results showing how remittances influence Loan Granted

\begin{tabular}{|c|c|c|c|c|}
\hline & & \multicolumn{3}{|c|}{ Loan Granted } \\
\hline & & B & Sig. & $\operatorname{Exp}(\mathbf{B})$ \\
\hline & $\begin{array}{l}\text { Received External } \\
\text { Remittance }\end{array}$ & -0.941 & .378 & .390 \\
\hline & Received Internal Remittance & $.382 * * *$ & .000 & 1.465 \\
\hline & Paid External Remittance & .370 & .310 & 1.448 \\
\hline & Paid Internal Remittance & $.727 * * *$ & .000 & 2.069 \\
\hline & HHSize & $-.104 * * *$ & .000 & .901 \\
\hline & MalesAbove15 & -.061 & .161 & .940 \\
\hline & FemalesAbove15 & $.082 * * *$ & .000 & 1.086 \\
\hline & MembersSHS & $.108^{*}$ & .017 & 1.114 \\
\hline & MembersTer & $.478^{* * * *}$ & .000 & 1.613 \\
\hline & AgeHead & -.004 & .061 & 0.996 \\
\hline & Constant & -2.295 & .000 & .101 \\
\hline Pseudo $\mathrm{R}^{2}$ & Cox \& Snell R Square & 0.18 & & \\
\hline & Nagelkerke R Square & 0.36 & & \\
\hline Omnibus Test & & $256.301 * * *$ & .000 & \\
\hline Hosmer and L & & 34.929 & .061 & \\
\hline
\end{tabular}

Source: Compiled by the author.

Households that receive internal remittances are seen to significantly influence loan acquisition. The result shows an odds ratio of 1.465 and coefficient of $0.382(\operatorname{Exp}(B)=1.465, p<0.001)$ supporting the view of Fajnzylber and Lopez (2008) that financial institutions are willing to give loans to households that they have enough information on as a result of frequent receipt of remittances. Households that paid out remittances to people within Ghana also have a significant impact on the acquisition of loans with an odds ratio of 2.069 more than households that do not receive internal remittances supporting previous studies (Anzoategui, 2014). Household size, though significant, negatively influences the probability of households receiving loans from financial institutions with odds ratio of less than 1 (0.901) indicating that the larger the household size, the less likely that the household will have their loans granted.

Certain household characteristics such as number of households that have female members who are 18 years and above, have significant impact on the probability that a household will receive a loan. This means that financial institutions are willing to grant loans to females than males. Again, the number of households with members having attained tertiary education has the highest odds ratio indicating a strong positively significant impact on loans acquisition. This confirms Mincer's (1974) assertion that education increases financial inclusion, specifically loan acquisition. Lastly, the result found a significant and positive relationship between loan grant and salaries. Households that have members who receive monthly salaries are almost twice likely to be granted loans than households whose members do not receive monthly salaries. 
Table 7. Logistic Regression results showing how remittances actually received influence Loan Granted

\begin{tabular}{|c|c|c|c|c|}
\hline & & \multicolumn{3}{|c|}{ Loan Granted } \\
\hline & & $\mathrm{B}$ & Sig. & $\operatorname{Exp}(\mathrm{B})$ \\
\hline & Received Internal Remittance & 0.08 & 0.732 & 1.083 \\
\hline & Paid External Remittance & -1.492 & 0.163 & 0.225 \\
\hline & Paid Internal Remittance & $0.772 * *$ & 0.001 & 2.164 \\
\hline & HHSize & -0.003 & 0.951 & 0.997 \\
\hline & MalesAbove15 & 0.03 & 0.75 & 1.031 \\
\hline & FemalesAbove15 & 0.071 & 0.106 & 1.074 \\
\hline & MembersSHS & -0.144 & 0.173 & 0.866 \\
\hline & MembersTer & $0.313^{* *}$ & 0.004 & 1.368 \\
\hline & AgeHead & -0.005 & 0.238 & 0.995 \\
\hline & Constant & -1.439 & 0.000 & 0.237 \\
\hline Pseudo $\mathrm{R}^{2}$ & Cox \& Snell R Square & 0.26 & & \\
\hline & Nagelkerke R Square & 0.39 & & \\
\hline Omnibus T & & $43.491 * * *$ & .000 & \\
\hline Hosmer an & & & .074 & \\
\hline
\end{tabular}

$* p<0.05, * * p<0.01, * * * p<0.001$

Source: Compiled by the author.

Table 7 shows the factors that interplayed in influencing financial institutions' decision to grant loans to some 1,954 households out of the 16,772 households that actually made a request for loans with financial institutions. The focus of this test is to find out how remittances influenced the probability that financial institutions will grant loans to applicant households when loan application was indeed made. It is observed that only households that pay internal remittances $(\operatorname{Exp}(B)=2.164, p=0.001)$ households that have members with tertiary education and $(\operatorname{Exp}(B)=1.368, p=0.004)$ are the factors that are significant and positively influence applicants' loans to be granted. A household that sent remittances within the country had 2.164 times likelihood to receive a loan from a bank than households that did not send remittances to others. Again, households that have members with tertiary education also had 1.368 chances of receiving loans from financial than households that do not have members with tertiary education. The result affirms some of the earlier finding in table 6 that financial institutions are willing to grant loans to applicant with tertiary level of education because of the minimum risk of default among such members. Households that have members who receive monthly salaries actually were twice more than households than households that do not receive any monthly salaries in terms of loans grants.

\section{Remittances and Bank Account Opening}

In this sub-section, direct logistic regression was performed to examine how remittances influence the chances of households opening a bank account with financial institutions, the third objective of this paper, on the part of households that engage in remittances. For simplicity purpose, and as done in the previous sub-sections, the coefficients (B), the p-values (Sig.) and the odds ratio $(\operatorname{Exp}(B)$ are reported in Table 8.

Table 8: Logistic Regression results showing how remittances influence opening of Bank Account

\begin{tabular}{|c|c|c|c|c|}
\hline & \multicolumn{3}{|c|}{ Bank Account } \\
\hline & & B & Sig. & $\operatorname{Exp}(B)$ \\
\hline & Received External Remittance & -.713 & .376 & .490 \\
\hline & Received Internal Remittance & $.345 * * *$ & .000 & 1.413 \\
\hline & Paid External Remittance & $1.044 * *$ & .007 & 2.841 \\
\hline & Paid Internal Remittance & .106 & .341 & 1.112 \\
\hline & HHSize & $-.036^{*}$ & .014 & .965 \\
\hline & MalesAbove15 & .015 & .648 & 1.015 \\
\hline & FemalesAbove15 & $-.086 * * *$ & .000 & .917 \\
\hline & MembersSHS & $.964 * * *$ & .000 & 2.622 \\
\hline & MembersTer & $2.129 * * *$ & .000 & 8.407 \\
\hline & AgeHead & $-.014 * * *$ & .000 & .986 \\
\hline & Constant & .000 & .996 & 1.000 \\
\hline \multirow[t]{2}{*}{ Pseudo $\mathrm{R}^{2}$} & Cox \& Snell R Square & .199 & & \\
\hline & Nagelkerke R Square & .266 & & \\
\hline Omnibus Test & & $3090.310 * * *$ & .000 & \\
\hline \multicolumn{2}{|c|}{ Hosmer and Lemshow Test } & $35.766^{* * *}$ & .063 & \\
\hline
\end{tabular}

$* p<0.05, * * p<0.01, * * * p<0.001$

Source: Compiled by the author. 
The result in Table 8 shows that households that received internal remittances have a high chance of opening accounts with financial institutions. The odds ratio of 1.413 indicates that households that received remittances from Ghana are over 1.4 times more likely to open an account than households that do not receive internal remittances. This is so because many of the internal transfers are often done with financial institutions.

Again, the result shows that households that sent remittances to others living outside Ghana are 2.841 times likely to open a bank account than other households that do not send remittances abroad. This explains that households that send remittances abroad will need to have an account with financial institutions in order to enjoy certain benefits like ATM transaction, online banking that may facilitate smooth transfer of remittances to people living outside Ghana.

Certain household characteristics in the model such household size, number of households that have female members who are 18 years and above significantly but negatively influence the probability that a household will have an official bank account. As expected, the paper found that households with members who are salaried workers are likely to have an official account with financial institutions. This is the case because most monthly salaries are paid through financial institutions and hence the likely tendency that such members will have an official account.

On education, we found that as members of households graduate from one level of education to the other (From SHS to tertiary institutions) the probability of the household opening an account increases accordingly. We also found that the number of households with members having tertiary education, which is the strongest predictor, is 8 times more likely to open an account than households that do not have members with tertiary level education. This indicates that, in the model and among the variables used, households with more educated members are more likely to have a bank account, most especially tertiary education.

\section{Control for Collateral}

The paper further takes into consideration assets that are owned by households which can serve as collateral for loans request and loans grant. Assets that serve as collateral in this paper include home appliances, lands and buildings and vehicles that are owned by the 16772 households.

Table 9. Logistic Regression results showing how remittances influence Loan Application when Collateral is considered

\begin{tabular}{|l|c|c|c|c|}
\hline \multicolumn{3}{|c|}{ Loan Application } & Sig. & Exp(B) \\
\hline & & B & 0.999 & 0.901 \\
\hline & ExtRemitRec & 19.53 & 0.993 \\
\hline & InterRemitRec & -0.232 & 0.139 & 0.597 \\
\hline & ExtRemitGiv & -0.516 & 0.15 & 0.557 \\
\hline & InterRemitGiv & 0.586 & 0.510 & 0.893 \\
\hline & HHSize & $-0.113^{* * *}$ & 0.000 & 0.977 \\
\hline & MalesAbove15 & -0.024 & 0.59 & 1.031 \\
\hline & FemaleAbove15 & 0.031 & 0.135 & 0.986 \\
\hline & MembersSHS & -0.014 & 0.763 & 1.085 \\
\hline & MembersTer & $0.081^{*}$ & 0.022 & 1.001 \\
\hline & AgeHead & 0.001 & 0.613 & 2.200 \\
\hline Pseudo R & Land \& Building & $0.675^{*}$ & 0.019 & 0.33 \\
\hline \multicolumn{2}{|c|}{ Vehicle } & 17.081 & 1 & 0.000 \\
\hline Omnibus Test & Appliances & -17.657 & 0.999 & \\
\hline Hosmer and Lemeshow Test & Cox \& Snell R Square & 0.06 & & \\
\hline
\end{tabular}

Source: Compiled by the author.

Table 9 presents the coefficients (B), the p-values (Sig.) and the odds ratio $(\operatorname{Exp}(B)$. We found that land and building owned by households is positively significant to loan application with odds ratio and P-Value of $(\operatorname{Exp}(B)=1.200, p=0.009)$ respectively. In essence, households that possess land and building are 1.2 times more likely to request for loans than households that do not own land and building. Household size has odds ratio of $(\operatorname{Exp}(B)=0.113, p=0.000)$ indicating that household size is significant but negatively related to loan request. Households with members that have attained tertiary education are also more likely to apply for loans with odds ratio and P-Values of $(\operatorname{Exp}(B)=1.085, p=0.022)$. 
Table 10. Logistic Regression results showing how remittances influence Loan Grant when Collateral is considered

\begin{tabular}{|c|c|c|c|c|c|}
\hline \multicolumn{6}{|c|}{ Loan Grant } \\
\hline & & & $\mathrm{B}$ & Sig. & $\operatorname{Exp}(\mathrm{B})$ \\
\hline \multirow[t]{13}{*}{ Step 1a } & ExtRemitRec & & 0.941 & 0.377 & 2.564 \\
\hline & InterRemitRec & & -0.381 & 0.343 & 0.684 \\
\hline & ExtRemitGiv & & -0.369 & 0.312 & 0.691 \\
\hline & InterRemitGiv & & 0.726 & 0.411 & 1.484 \\
\hline & HHSize & & $-0.104 * * *$ & 0.000 & 0.901 \\
\hline & MalesAbove15 & & -0.061 & 0.163 & 0.941 \\
\hline & FemalesAbove15 & & $0.082 * * *$ & 0.000 & 1.085 \\
\hline & MembersSHS & & $0.108^{* *}$ & 0.017 & 1.114 \\
\hline & MembersTer & & $0.479 * * *$ & 0.000 & 1.614 \\
\hline & AgeHead & & -0.004 & 0.062 & 0.996 \\
\hline & Land\& Building & & $0.585^{*}$ & 0.043 & 1.324 \\
\hline & Vehicle & & 16.573 & 0.786 & 1.5763 \\
\hline & Appliances & & -17.226 & 0.999 & 0.543 \\
\hline \multirow[t]{2}{*}{ Pseudo $\mathrm{R}^{2}$} & Cox \& Snell R Square & 0.018 & & & \\
\hline & Nagelkerke R Square & 0.036 & & & \\
\hline \multicolumn{3}{|c|}{ Omnibus Test } & $259.41 * * *$ & 0.000 & \\
\hline \multicolumn{3}{|c|}{ Hosmer and Lemeshow Test } & 33.59 & 0.620 & \\
\hline
\end{tabular}

Source: Compiled by the author.

Table 10 shows the results of how remittances influence the probability that a household will be granted loan by financial institutions. The table reports the coefficients (B), the p-values (Sig.) and the odds ratio Exp (B). From Table $X$, land and building is significant and positively correlated with loan grant with odds ratio and PValue of $(\operatorname{Exp}(B)=1.324, p=0.043)$ respectively. Households that own land and building are 1.324 times more likely to be granted loans than households that do not have land and building. Other variables that are significant and positively impact the chances of a household being granted a loan are households with female members who are 18 years and above. Again, households whose members have attained SHS and tertiary education are likely to be granted loans with odds ratio and $(\operatorname{Exp}(B)=1.114, p=0.000)$ respectively. Household size, however, reduces the chances that a household will be granted loans. This may be due to the high dependency ratio that exists in households in Ghana specifically the 16,772 households under consideration.

Table 11. Logistic Regression results showing how remittances influence Bank Account Opening when Collateral is considered

\begin{tabular}{|l|l|l|l|l|}
\hline \multicolumn{5}{|c|}{ Bank Account } \\
\hline
\end{tabular}

Source: Compiled by the author.

Table 11 shows the extent to which remittances influence households' decision to have an official account with formal financial institution after considering assets that can serve as collateral. The table shows that households that receive internal remittances and pay external remittances have positive probability of opening a bank account with odds ratio and P-Values of $(\operatorname{Exp}(B)=1.707, p=0.031)$ and $(\operatorname{Exp}(B)=1.352, p=$ $0.023)$ respectively. From table 11, households that receive internal remittances are 1.7 times more likely to 
have an account with financial institutions than households that do not receive remittances with P-Value of 0.031 .

Again, households are 1.352 times more likely to open an account to enhance the transactions than households that do not send remittances abroad. In essence a unit increase in the number of households that sends remittances abroad increases the probability that households will open an account with formal financial institutions by 1.045 .

Human capital used in the model in the form of formal education shows that education has a higher tendency on improving bank account opening among households as found in the results in Table 11 when collateral was not factored. Again, variables in the model that represent households' characteristics (age in years of household heads, number of female members in a household who are 18 years and above and household size) is significant but negatively influence the probability of a household opening account with financial institutions. Households that have land and buildings have a positive probability of opening an account with an odds ratio and P-value of $(\operatorname{Exp}(B)=1.996, p=0.002)$ respectively. These households are likely to have an account with financial institutions, among other reasons, to increase their chances of acquiring loans when the need arises

\section{Diagnostics for the results}

The study employed two main diagnostics to assess the adequacy of all the results obtained. The omnibus test assesses the overall fitness of the model and thus it is based on the null hypothesis that there is no significant joint effect of the independent variables on the dependent variable. The $p$-value of the omnibus test in all the regression results led to the rejection of the null hypotheses and thus the conclusion is that all the models estimated are fit. Hosmer-Lemeshow test assesses the goodness of fit test of a regression model, specifically a probit or logit regression. The null hypothesis of the Hosmer-Lemeshow test is that there is a "non-poor" fit. Thus, it could be observed from all the results that all the regression estimations are fit.

\section{Conclusion and Recommendations}

This paper empirically investigated the extent to which both internal and international remittances impact financial inclusion in Ghana. It is concluded that internal remittance significantly influences financial inclusion in Ghana. Internal remittances positively and significantly influence financial inclusion in all the three objectives (loan request, loan grant and bank account).

On external remittances, the paper concludes that external remittances do not significantly influence financial inclusion in Ghana. Specifically, external remittances do not to have any significant impact on loan application and loan grant but have a positive and a significant impact on bank account opening.

On ownership of assets, the paper concludes that a household with land and building increases the probability of applying for loan from financial institutions. Thus, collateral strengthens access to household credit. Physical asset collaterals weigh more than expected remittances in loan application success.

Internal remittances have higher potential to improve financial inclusion in Ghana than international remittances. Remittances will have a very little impact on financial inclusion when financial institutions demand collateral security to foster loan application and grant.

\section{Recommendations}

Strategies to improve internal remittances is recommended to improve financial inclusion and deepen economic development

Enhance environment for remittance especially internal remittance to make it flexible deepen financial inclusion.

Use internal remittances as collateral for loan by households.

\section{Acknowledgment}

Mr. David Korsah is acknowledged for helping in data extraction. Mr. Mac Abeka Junior is also acknowledged for making valuable comments. 
Financial Markets, Institutions and Risks, Volume 4, Issue 3, 2020 ISSN (online) - 2521-1242 ISSN (print) - 2521-1250

\section{References}

1. Abdul-Mumuni, A., \& Quaidoo, C. (2016). Effect of International Remittances on Inflation in Ghana Using the Bounds Testing Approach. Business and Economic Research,6(1), 192-209. http://dx.doi.org/10.5296/ber.v6i1.8635

2. Abida, Z., \& Sghaier, I. M. (2014). Remittances, Financial Development and Economic Growth: The Case of North African Countries. Romanian Economic Journal, 17(51).

3. Adams, R., Lopez-Feldman, A., Mora, J., Taylor, J. E., DeWind, J., \& Holdaway, J. (2008). Remittances, inequality and poverty: Evidence from rural Mexico. Migration and development within and across borders: Research and policy perspectives on internal and international migration, 101-130. http://www.rejournal.eu/sites/rejournal.versatech.ro/files/articole/2014-03-01/1897/7zouheirimen.pdf

4. Aga, G. A., \& Peria, M. S. M. (2014). International remittances and financial inclusion in Sub-Saharan Africa. The World Bank. https://doi.org/10.1596/1813-9450-6991

5. Aggarwal, R., Demirgüç-Kunt, A., \& Peria, M. S. M. (2011). Do remittances promote financial development? Journal of Development $\quad$ Economics, 96(2), 255-264. https://doi.org/10.1016/j.jdeveco.2010.10.005

6. Ajefu, J. B., \& Ogebe, J. O. (2019). Migrant remittances and financial inclusion among households in Nigeria. Oxford Development Studies, 47(3), 319-335. https://doi.org/10.1080/13600818.2019.1575349

7. Ambrosius, C. (2012). Are remittances a" catalyst" for financial access? Evidence from Mexican household data (No. 2012/8). School of Business \& Economics, Discussion Paper: Economics. http://dx.doi.org/10.17169/FUDOCS document 000000013525

8. Andersson, L. (2014). Migration, remittances and household welfare in Ethiopia. file:///C:/Users/Proff/AppData/Local/Temp/wp2014-004.pdf

9. Anzoategui, D., Demirgüç-Kunt, A., \& Martínez Pería, M. S. (2011). Remittances and financial inclusion: evidence from El Salvador. The World Bank. https://doi.org/10.1596/1813-9450-5839

10. Bodomo, A. (2013). African diaspora remittances are better than foreign aid funds. World Economics, 14(4), 21-29. https://scholar.google.com/scholar?hl=en\&as sdt=0\%2C5\&q=Bodomo\%2C + A. $+\% 282013 \% 29 .+$ African + diaspora + remittances + are + better + than + foreign+aid + funds. + World + Econo mics $\% 2 \mathrm{C}+14 \% 284 \% 29 \% 2 \mathrm{C}+21-29 . \& \mathrm{btnG}=$

11. Busch, C., Kuckulenz, A., \& Le Manchec, M. H. (2002). Worker Remittances and Capital Flows (No. 1130). Kiel Working Paper. http://hdl.handle.net/10419/17803

12. Catrinescu, N., Leon-Ledesma, M., Piracha, M., \& Quillin, B. (2009). Remittances, institutions, and economic growth. World Development, 37(1), 81-92. https://doi.org/10.1016/j.worlddev.2008.02.004

13. Coulibaly, D. (2015). Remittances and financial development in Sub-Saharan African countries: A system approach. Economic Modelling, 45, 249-258. https://doi.org/10.1016/j.econmod.2014.12.005

14. Cuadros-Meñaca, A. (2020). Remittances, health insurance, and pension contributions: Evidence from Colombia. World Development, 127, 104766. https://doi.org/10.1016/j.worlddev.2019.104766

15. De Haas, H. (2010). Migration and development: A theoretical perspective 1. International migration review, 44(1), 227-264. https://doi.org/10.1111/j.1747-7379.2009.00804.x

16. Eftimoski, D., \& Josheski, D. (2020). Reopening the debate on the relationship among remittances, household consumption stability and economic growth in emerging markets. International Journal of Emerging Markets. https://doi.org/10.1108/IJOEM-02-2020-0160

17. Fajnzylber, P., \& Lopez, J. H. (Eds.). (2008). Remittances and development: lessons from Latin America. The World Bank. https://doi.org/10.1596/978-0-8213-6870-1

18. Freund, C., \& Spatafora, N. (2005). Remittances: transaction costs, determinants, and informal flows. The World Bank. https://doi.org/10.1596/1813-9450-3704

19. Gapen, M. T., Chami, M. R., Montiel, M. P., Barajas, M. A., \& Fullenkamp, C. (2009). Do workers' remittances promote economic growth? (No. 9-153). International Monetary Fund. https://d1wqtxts1xzle7.cloudfront.net/40342752/wp09153.pdf?1448396560=\&response-contentdisposition=inline $\% 3 \mathrm{~B}+$ filename $\% 3 \mathrm{DDo}$ Workers_Remittances_Promote_Economic.pdf\&Expires $=160$ 0444834\&Signature=RU3ObhW8FDr70enrGmwArXbhw3ZZZMaXvjDQuYaNs8Tb0Qey31PAGqDfFe ZBLCdL7oE46A1WqDLctSh0juufY tbal0 bzwb4inA9XsSIVho9L0g4cwKoqhf86uBoG3oq0i14hhHZr 6f $\sim$ YMweh9Y8oUF8uc4f1k0YtJmNuFHm WiUmLHpioesPK127vloQ4Nv9rW4o cxx4bVpFYmBUH GZXWCSfpgga0dsozlLkC0ywjTpawKnk5tUHX0qDpbjSaTgsaz3ECZx2rC8uYD4SHFNjcIBa01BmawU2s0O2GPkMHoa3hR 2iT11 fsq 52ow10oe2sMGEhysx9iTSDrTrw \&Key-Pair-Id=APKAJLOHF5GGSLRBV4ZA 
20. Gatsi, J., Idun, A. A., \& Mensah, F. (2020). Monetary policy and financial development in Africa: Do governance mechanisms matter? Journal of Economic and Financial Sciences, 13(1), 1-13. https://hdl.handle.net/10520/EJC-1d2bba7616

21. Gautam, D. P. (2019). Do Remittances Promote Financial Inclusion? In Economic and Political Institutions and Development (pp. 91-108). Springer, Cham. https://doi.org/10.1007/978-3-030-0604976

22. Githaiga, P. N., \& Kabiru, C. G. (2014). Remittances as a determinant of financial sector development. Journal of business economics and finance, 3(4). https://dergipark.org.tr/en/pub/jbef/issue/32409/360444

23. Githaiga, P. N. (2014). Do Remittances Stimulate Private Sector Investment? A Case of Sub-Saharan Africa. European Journal of Business and Management, 6, 29. http://citeseerx.ist.psu.edu/viewdoc/download?doi=10.1.1.678.3556\&rep=rep1\&type=pdf

24. Giuliano, P., \& Ruiz-Arranz, M. (2009). Remittances, financial development, and growth. Journal of Development Economics, 90(1), 144-152. https://doi.org/10.1016/j.jdeveco.2008.10.005

25. Gupta, S., Pattillo, C. A., \& Wagh, S. (2009). Effect of remittances on poverty and financial development in Sub-Saharan Africa. World development, 37(1), 104-115. https://doi.org/10.1016/j.worlddev.2008.05.007

26. Helen, T., \& Lensik, R. (2007). Remittances and Financial Inclusion in Development. Research paper, UN-WIDER, United Nation University (UNU), (2007/49).

27. Imai, K. S., Gaiha, R., Ali, A., \& Kaicker, N. (2014). Remittances, growth and poverty: New evidence from Asian countries. Journal of Policy Modeling, 36(3), 524-538. https://doi.org/10.1016/j.jpolmod.2014.01.009

28. Irving, J., Mohapatra, S., \& Ratha, D. (2010). Migrant remittance flows: findings from a global survey of central banks. The World Bank. https://doi.org/10.1016/j.jpolmod.2014.01.009

29. Kapur, D. (2003). Remittances: The new development mantra? United Nations Conference on Trade and Development, Geneva.

30. Naceur, S. B., Chami, R., \& Trabelsi, M. (2020). Do Remittances Enhance Financial Inclusion in LMICs and in Fragile States? (No. 20/66). International Monetary Fund. https://ssrn.com/abstract=3630155

31. Lipton, M. (1980). Migration from rural areas of poor countries: the impact on rural productivity and income distribution. World development, 8(1), 1-24. https://doi.org/10.1016/0305-750X(80)90047-9

32. Lopez, H., Bussolo, M., \& Molina, L. (2007). Remittances and the real exchange rate. https://doi.org/10.1596/1813-9450-4213

33. Monahov, A. (2020). Stress-testing a shock to remittances in a post-Covid world-what impact on liquidity? https://mpra.ub.uni-muenchen.de/id/eprint/101442

34. Mbutor, M. O., \& Uba, I. A. (2013). The impact of financial inclusion on monetary policy in Nigeria. Journal of Economics and International Finance, 5(8), 318-326. DOI: 10.5897/JEIF2013.0541

35. Mincer, J. (1974). Schooling, Experience, and Earnings. Human Behavior \& Social Institutions No. 2. https://eric.ed.gov/?id=ED103621

36. Nyamongo, E. M., Misati, R. N., Kipyegon, L., \& Ndirangu, L. (2012). Remittances, financial development and economic growth in Africa. Journal of economics and business, 64(3), 240-260. DOI: $10.1016 /$ j.jeconbus.2012.01.001

37. Ojapinwa, T. V., \& Bashorun, O. T. (2014). Do Workers' Remittances Promote Financial Development in Sub-Sahara Africa Countries? International Journal of Financial Research,5(2), 151. https://ideas.repec.org/a/jfr/ijfr11/v5y2014i2p151-159.html

38. Quartey, P.,Ackah, C., \&Lambon-Quayefio,M.P. (2019). Inter-linkages between remittances and savings in Ghana. International Journal of Social Economics, 46(1), 152-166. https://doi.org/10.1108/IJSE-122017-0618

39. Ratha, D. (2003). Workers' remittances: an important and stable source of external development finance. Global development finance, 2003, 157-175. https://elibrary.worldbank.org/doi/pdf/10.1596/08213-5794-8\#page $=41$

40. Ruiz, I., Vargas-Silva, C. (2010). Monetary policy and international remittances. The Journal of Developing Areas, 43(2), 173-186. https://www.jstor.org/stable/40376256

41. Ruiz-Arranz, M., Giuliano, P. (2005). Remittances, financial development, and growth (No. 5-234). International Monetary Fund. https://doi.org/10.1016/j.jdeveco.2008.10.005 
42. Sarma, M. (2008). Index of financial inclusion (No. 215). Working paper. http://hdl.handle.net/10419/176233

43. Shankar, S. (2013). Financial Inclusion in India: Do Microfinance Institutions Address Access Barriers. ACRN Journal of Entrepreneurship Perspectives, 2(1), 60-74. https://www.semanticscholar.org/paper/Financial-Inclusion-in-India-\%3A-Do-MicrofinanceShankar/4ad43e14111bd6a5ac1bd61949e16d3b0cdbd90e\#paper-header

44. Siddique, A., Selvanathan, E. A., \& Selvanathan, S. (2012). Remittances and economic growth: empirical evidence from Bangladesh, India and Sri Lanka. Journal of development studies, 48(8), 1045-1062. https://doi.org/10.1080/00220388.2012.663904

45. Sulemana, I., Bugri Anarfo, E., \& Quartey, P. (2019). International remittances and household food security in Sub-Saharan Africa. Migration and Development, 8(2), 264-280. https://doi.org/10.1080/00220388.2012.663904

46. Taylor, E. J. (1999). The new economics of labour migration and the role of remittances in the migration process. International migration, 37(1), 63-88. https://doi.org/10.1080/00220388.2012.663904

47. Todaro, M. P. (1969). A model of labor migration and urban unemployment in less developed countries. The American economic review, 59(1), 138-148. https://www.jstor.org/stable/1811100

48. Tweneboah, G., Gatsi, J. G., \& Asamoah, M. E. (2019). Financial development and dollarization in Ghana: an empirical investigation. Cogent Economics \& $\quad$ Finance, 7(1), 1663699. https://doi.org/10.1080/23322039.2019.1663699

49. Woodruff, C. M., \& Zenteno, R. (2001). Remittances and microenterprises in Mexico. http://dx.doi.org/10.2139/ssrn.282019 